\title{
Analytical review of 664 cases of penetrating buttock trauma
}

\author{
Raimundas Lunevicius ${ }^{*}$ and Klaus-Martin Schulte
}

\begin{abstract}
A comprehensive review of data has not yet been provided as penetrating injury to the buttock is not a common condition accounting for $2-3 \%$ of all penetrating injuries. The aim of the study is to provide the as yet lacking analytical review of the literature on penetrating trauma to the buttock, with appraisal of characteristics, features, outcomes, and patterns of major injuries. Based on these results we will provide an algorithm. Using a set of terms we searched the databases Pub Med, EMBASE, Cochran, and CINAHL for articles published in English between 1970 and 2010. We analysed cumulative data from prospective and retrospective studies, and case reports. The literature search revealed 36 relevant articles containing data on 664 patients. There was no grade A evidence found. The injury population mostly consists of young males (95.4\%) with a high proportion missile injury (75.9\%). Bleeding was found to be the key problem which mostly occurs from internal injury and results in shock in $10 \%$. Overall mortality is $2.9 \%$ with significant adverse impact of visceral or vascular injury and shock $(P<0.001)$. The major injury pattern significantly varies between shot and stab injury with small bowel, colon, or rectum injuries leading in shot wounds, whilst vascular injury leads in stab wounds $(P<0.01)$. Laparotomy was required in $26.9 \%$ of patients. Wound infection, sepsis or multiorgan failure, small bowel fistula, ileus, rebleeding, focal neurologic deficit, and urinary tract infection were the most common complications. Sharp differences in injury pattern endorse an algorithm for differential therapy of penetrating buttock trauma. In conclusion, penetrating buttock trauma should be regarded as a life-threatening injury with impact beyond the pelvis until proven otherwise.
\end{abstract}

Keywords: buttock injury, penetrating trauma, shot wound, stab wound

\section{Background}

The buttock comprises the lateral half of the lower most sagittal zone of the torso [1] where there is a particularly high density of vital structures above and below the peritoneum in the pelvis [2,3]. Sparse evidence points to the frequency of life-threatening visceral and vascular injuries in patients with penetrating trauma to the buttock $[2,4,5]$. Pelvic anatomy results in the possibility of major complications or death following penetrating buttock injury in any path of trajectory and in absence of hard vascular, abdominal, or pelvic signs [4].

A comprehensive review of data has not yet been provided as penetrating injury to the buttock is not a common condition accounting for $2-3 \%$ of all penetrating injuries [3,6-10]. Four previous reviews of the literature

\footnotetext{
* Correspondence: rlunevichus@yahoo.com Major Trauma Centre, King's College Hospital NHS Foundation Trust, King's Health Partners Academic Health Sciences Centre, Denmark Hill, London, SE5 9RS, UK
}

(C) 2011 Lunevicius and Schulte; licensee BioMed Central Ltd. This is an Open Access article distributed under the terms of the Creative Commons Attribution License (http://creativecommons.org/licenses/by/2.0), which permits unrestricted use, distribution, and reproduction in any medium, provided the original work is properly cited. sistent patterns, peculiarities, and management [6-9].

The purpose of this study is to provide an analytical review of the literature on penetrating trauma to the buttock and to appraise the characteristics, features, outcomes, and patterns of major injuries. Recognition of specific patterns should enhance management of this trauma.

\section{Methods}

The Entrez PubMed interface of MEDLINE database, EMBASE, Cochran, and CINAHL databases were searched using the following Medical Subject Heading (MeSH) keywords: "Injuries", "Wounds and Injuries", "Wound Penetrating"; each of these keywords was combined with the keyword "Buttocks". The term 'Penetrating Gluteal Injuries' was also used. This resulted in 1021 titles and abstracts of studies related to these terms 
which were then read on the basis of English language and relevance.

Commentaries and literature reviews were also taken into account. We excluded articles relating to blunt injury, acupuncture injury, intragluteal injection injury, needle stick accidents, iatrogenic injury of the gluteal arteries, wound closure, reconstructive surgery of gluteal defects, wound botulism, bone fracture complications, injury from ultraviolet light, burn injury, true aneurisms, malignancies, and animal studies.

Relevant studies on penetrating buttock injury in acute trauma setting were grouped and categorised chronologically. Clustered and individual data regarding the demographic characteristics, mechanism of injury, clinical mode of presentation, imaging, buttock zone wounded, injuries, management strategy, complications, and final outcome were accumulated from all the studies, either prospective or retrospective, and case reports. When calculations in main series were impossible due to the lack of particular data, they were performed through the use of informative subset with indication of the exact number of entered cases.

In order to assess outcomes of visceral, vascular, skeletal, nerve injuries as well as outcomes of major surgery after stabbing or shootings, the $95 \%$ confidence intervals of odds ratios were calculated. In order to detect differences in injury related with stabbing or shooting patterns and outcomes between two independent proportions a Z-test was chosen and employed as both sample sizes were greater than 30 . The two-tailed test was used to assess the null hypothesis. Chi-square test with Yates' correction was employed to compare categorical "alive - dead" outcome. Two-tailed p values were calculated where by $P<0.05$ was considered to indicate statistical significance. Microsoft Office XP Excel 2007 Worksheets were used for accumulation and analysis of data.

\section{Results}

\section{Literature search}

We identified four literature reviews [6-9], two prospective studies [11,12], twelve retrospective reviews [2-5,10,13-19], seventeen papers with case reports [6,8,20-33], and three commentaries [34-36]. 31 publication contributed patient data on a total of 664 patients. Although individual studies chosen for review had some variations in specific measures, they were conceptually similar. No articles reported population-based data on overall and type-specified buttock injury in relation to incidence and mortality. There were no systematic reviews or prospective randomised controlled trials identified. A summary of two prospective and twelve retrospective studies are shown in Table 1.

\section{Patient data}

The analysis includes 664 patients for whom the minimal dataset was identified. Overall, $95.4 \%$ of cases (621/ 654) were males, and the median age was 29 (range 12$70)$. Missile injury accounted for $75.9 \%(504 / 664)$ and was mainly due to shooting $(68.8 \%, 457 / 664)$, and rarely blasting (7.1\%, 47 cases). Injury rate for stabbings was $23.8 \%(158 / 664)$. Impalement was rare with only $0.3 \%$ of cases (2/664). For 97 patients the zonal distribution was known, where by $66.0 \%(n=64)$ were related to the upper zone of the buttock.

Clinical presentation on admission was known in 654 patients. 74 patients $(11.3 \%)$ were regarded haemodynamically unstable and $56(8.6 \%)$ were diagnosed to be in haemorrhagic shock. Peritoneal irritation was present in 48 (7.3\%), gross rectal blood in 41 (6.3\%), and gross haematuria in 27 (4.1\%) patients. Massive external bleeding was documented in 15 patients, false aneurysm formation in 12, absence of distal pulse or cold painful leg in two, groin hematoma in two, and severe bone pain in three patients.

Initial diagnostic procedures were described by the authors as follows: diagnostic proctosigmoidoscopy in 295 (45.1\%), angiography in 47 (7.2\%), urology imaging (cystography, intravenous pyelography, urethrography) in $27(4.1 \%)$ patients, and CT-scan for $10(1.5 \%)$ patients. Retrograde irigoscopy and diagnostic peritoneal lavage were mentioned in a few reports.

\section{Treatment modalities}

The treatment approaches were described in 654 patients. 176 (26.9\%) patients underwent emergency laparotomy. 40 (6.1\%) patients required extended gluteal surgery. The interventional radiology procedures were used as sole modality to control bleeding or target bullets in 12 patients (1.8\%). 356 (54.4\%) patients were observed without major procedure. Other surgical procedures such as debridement under general anaesthesia were performed in $16.5 \%(\mathrm{n}=108)$ of patients.

Laparotomy and extended gluteal surgery was performed for 207 patients in the subset of 615 patients with gunshot or stab trauma (33.7\%). Laparotomy was performed on $12.0 \%$ of stabbed patients $(19 / 158)$ and $32.4 \%(148 / 457)$ of patients that were shot (OR, 0.29; CI, 0.17-0.48; $\mathrm{Z}$ value 4.857; $P<0.001$ ). Extended gluteal surgery was more often performed in the group of patients with stab injuries to the buttock: $33 / 158$ $(21.0 \%)$ operations in contrast to $7 / 457$ (1.5\%) operations in gunshot victims (OR, 16.97; CI, 7.33-39.29; Z value $8.32 ; P<0.001)$.

\section{Outcomes \\ Mortality}

Overall mortality rate was $2.9 \%$ (19/664). In terms of stabbing injury the mortality rate was $3.8 \%(6 / 158)$ and 


\section{Table 1 Major endpoints of two prospective [11,12] and twelve retrospective reviews on penetrating buttock injury in acute trauma setting}

\begin{tabular}{|c|c|c|c|c|c|c|c|c|c|c|c|c|c|c|}
\hline $\begin{array}{l}\text { Study/ } \\
\text { reference }\end{array}$ & $\begin{array}{l}\text { Period } \\
\text { years }\end{array}$ & Patients & Male & $\begin{array}{c}\text { Mean } \\
\text { age }\end{array}$ & $\begin{array}{l}\text { Viscus/major } \\
\text { vessel injury }\end{array}$ & $\begin{array}{l}\text { Bony ring } \\
\text { injury }\end{array}$ & $\begin{array}{l}\text { Mean } \\
\text { ISS }\end{array}$ & $\begin{array}{c}\text { Major } \\
\text { surgery* }\end{array}$ & $\begin{array}{l}\text { Overall } \\
\text { mortality }\end{array}$ & $\begin{array}{l}\text { Morbidity in } \\
\text { survivals }\end{array}$ & $\begin{array}{l}\text { Concominant } \\
\text { injuries }\end{array}$ & $\begin{array}{l}\text { Hospital } \\
\text { stayt }\end{array}$ & $\begin{array}{l}\text { Cited } \\
\text { articles }\end{array}$ & Contribution/concern \\
\hline $\begin{array}{l}\text { Velmahos et al. } \\
\text { [11] (1997) }\end{array}$ & 1 & 59 & 58 & 23 & $17(29 \%)$ & $5(8 \%)$ & - & 19(32.2\%) & 0 & $3(15.8 \%)$ & High & 7.2 & 11 & $\begin{array}{l}\text { Clinical examination is } \\
\text { very accurate }\end{array}$ \\
\hline $\begin{array}{l}\text { Velmahos et al. } \\
\text { [12] (1998) }\end{array}$ & 1 & 10 & - & - & - & - & - & - & 0 & - & - & - & 14 & $\begin{array}{l}\text { Clinical examination is a } \\
\text { reliable predictor }\end{array}$ \\
\hline $\begin{array}{l}\text { Maull et al. [13] } \\
\text { (1979) }\end{array}$ & 5 & 15 & 11 & 29 & $6(54.5 \%)$ & - & - & 12 & 0 & $5(33 \%)$ & 0 & 12 & 0 & $\begin{array}{l}\text { Liberal laparotomy } \\
\text { advocated }\end{array}$ \\
\hline $\begin{array}{l}\text { Ivatury et al. [4] } \\
\text { (1982) }\end{array}$ & 4 & 60 & 57 & - & $16(26.7 \%)$ & $3(5 \%)$ & - & $\begin{array}{c}16 \\
(26.7 \%)\end{array}$ & $2(3 \%)$ & $14(23 \%)$ & - & 2 vs 18 & 3 & Aggressive management \\
\hline $\begin{array}{l}\text { Vo et al. [5] } \\
\text { (1983) }\end{array}$ & 5 & 20 & 18 & 32 & $5(25 \%)$ & $2(10 \%)$ & - & $12(60 \%)$ & 0 & $5(25 \%)$ & $10(50 \%)$ & - & 2 & $\begin{array}{l}\text { Bullet's trajectory is } \\
\text { important }\end{array}$ \\
\hline $\begin{array}{l}\text { Fallon et al. [14] } \\
\text { (1988) }\end{array}$ & - & 51 & 43 & 28.9 & $16(31 \%)$ & 0 & - & 25 (49\%) & 0 & $4(8 \%)$ & High & - & 4 & $\begin{array}{l}\text { Thorough evaluation and } \\
\text { all investigations }\end{array}$ \\
\hline $\begin{array}{l}\text { Gilroy et al. [15] } \\
\text { ( 1992) }\end{array}$ & 6 & 8 & 7 & 33 & 8 & - & - & 8 & $2(25 \%)$ & 0 & 0 & - & 9 & $\begin{array}{l}\text { Danger of gluteal incision: } \\
\text { vessels }\end{array}$ \\
\hline $\begin{array}{l}\text { Mercer et al. [3] } \\
\text { (1992) }\end{array}$ & 6 & 81 & 75 & 26 & $18(22 \%)$ & $4(5 \%)$ & - & $26 \%(21)$ & $1(1.2 \%)$ & - & - & - & 6 & $\begin{array}{l}\text { Two zones of buttock: } \\
\text { upper vs lower }\end{array}$ \\
\hline $\begin{array}{l}\text { Ferraro et al. } \\
\text { [16] (1993) }\end{array}$ & 2 & 70 & 68 & 25 & $34(49 \%)$ & $7(17 \%)$ & $\begin{array}{l}11(1- \\
45)\end{array}$ & 34 (49\%) & $3(4 \%)$ & - & - & - & 8 & Sigmoidoscopy advocated \\
\hline $\begin{array}{l}\text { DiGiacomo et } \\
\text { al. [2] (1994) }\end{array}$ & 3 & 73 & 71 & - & $24(33 \%)$ & $10(14 \%)$ & - & 27 (37\%) & $1(1.4 \%)$ & $9(12 \%)$ & - & - & 10 & $\begin{array}{l}\text { Transpelvic bullet } \\
\text { trajectory: surgery }\end{array}$ \\
\hline $\begin{array}{l}\text { Makrin et al. } \\
\text { [17] (2001) }\end{array}$ & 5 & 17 & 17 & 27 & $4(23.5 \%)$ & 0 & - & $2(11.8 \%)$ & 0 & $1(6 \%)$ & 0 & $4(1-16)$ & 5 & $\begin{array}{l}\text { Upper zone wounds carry } \\
\text { higher risk }\end{array}$ \\
\hline $\begin{array}{l}\text { Susmallian et al. } \\
{[18](2005)}\end{array}$ & 5 & 39 & 38 & - & $4(10.5 \%)$ & - & - & $2(5.1 \%)$ & 0 & 0 & 0 & - & 6 & Meticulous observation \\
\hline $\begin{array}{l}\text { Ceyran et al.[19] } \\
\text { (2009) }\end{array}$ & 17 & 27 & 27 & - & - & 0 & - & 25 (93\%) & $3(11.1 \%)$ & $1(4.2 \%)$ & 0 & $8(7-11)$ & 7 & $\begin{array}{l}\text { Surgical approach and } \\
\text { technique, if needed }\end{array}$ \\
\hline $\begin{array}{l}\text { Lesperance et. } \\
\text { [10] (2009) }\end{array}$ & 1.33 & 115 & 113 & 28 & 36 (31\%) & 40 (35\%) & $\begin{array}{l}13(1- \\
75)\end{array}$ & 87 (76\%) & $7(6 \%)$ & $16(14 \%)$ & $66(57 \%)$ & - & 24 & $\begin{array}{l}\text { Military surgery } \\
\text { experience }\end{array}$ \\
\hline Summary & $1-17$ & $8-115$ & Most & Young & $10.5-54.5 \%$ & $0-35 \%$ & $\begin{array}{c}11- \\
13\end{array}$ & $5.1-93 \%$ & $0-25 \%$ & $0-33 \%$ & High & Long & $0-24$ & $\begin{array}{l}\text { Dangerous injury/ } \\
\text { Contingencies possible }\end{array}$ \\
\hline
\end{tabular}

*Major surgery: laparotomy, suprapubic cystostomy, massive/operating room gluteal surgery (massive debridement included). †Hospital stay - mean/average. Values in parenthesis are percentages. 
2.6\% (13/504) following missile injuries. Mortality rate due to gunshot injuries was $2.2 \%(10 / 457) .6 .4 \%$ (3/47) of patients admitted for blast injuries had died. Both patients treated for impalement survived. Details related to each fatality due to penetrating injuries to the buttock are demonstrated in Table 2. Hypovolaemic shock, major surgical intervention, and visceral and/or vascular injury are all factors which have a significant impact on a lethal outcome (Table 3).

\section{Morbidity}

The authors described 18 specific postoperative complications. As they did not adhere to a set of auditable complications, the following figures have mere descriptive value: wound infection $(\mathrm{n}=16)$, sepsis or multiorgan failure $(\mathrm{n}=10)$, small bowel fistula $(\mathrm{n}=7$ via laparotomy; $\mathrm{n}=1$ via gluteal wound), prolonged ileus or transient obstruction $(n=6)$, rebleeding $(n=5)$, local neurologic dysfunction or weakness of leg $(n=5)$, urinary tract infection $(n=4)$, myocardial infarction $(n=3)$, sacral decubitus $(\mathrm{n}=3)$, stroke $(\mathrm{n}=2)$, pleuropulmonary dysfunction $(\mathrm{n}=2)$, thrombophlebitis/thrombosis ( $\mathrm{n}$ = 2), and compartment syndrome of the lower extremity, perirectal hematoma, acute renal failure, paraplegia, malignant hypothermia, impotence $(\mathrm{n}=1$ for each complication). The seven most common complications constituted $75 \%$ of all complications (54 cases). 17 $(2.6 \%)$ patients needed early postoperative reintervention.

\section{Patterns of major injuries \\ Pattern of major injuries related with penetrating trauma to the buttock}

There were 615 cases of penetrating buttock injuries caused by stabbing or shooting after exclusion of blasting $(n=47)$ and impaled injuries $(n=2)$. There were 292 injuries to viscera, named vessels, bony pelvis, and nerves. Injuries of viscera $(n=173 ; 28.1 \%)$ prevail over injuries to major vessels $(\mathrm{n}=81 ; 13.2 \%)$, bony pelvis $(29$ cases; $4.7 \%)$, or regional nerves $(n=9 ; 1.5 \%)$. Lumbosacral $(n=4)$ and sciatic nerve injuries $(n=5)$ were rare.

The details of major injuries due to penetrating trauma to the buttock is shown in Figure 1. 30 anatomical terms were used to describe a particular injury type. The small bowel (8.3\%), colon (6.3\%), superior gluteal artery $(5.4 \%)$, rectum $(4.9 \%)$, bony pelvis $(4.4 \%)$, bladder $(3.7 \%)$, and iliac artery $(2.0 \%)$ were on the top of the

Table 2 Deaths due to penetrating injuries to the buttock in series of 664 cases

\begin{tabular}{|c|c|c|c|c|c|c|c|c|c|c|c|c|}
\hline Author & $\begin{array}{c}\text { Case } \\
\text { no }\end{array}$ & Age & Gender & $\begin{array}{c}\text { Injury } \\
\text { Mechanism }\end{array}$ & $\begin{array}{l}\text { Buttock } \\
\text { or zone }\end{array}$ & $\begin{array}{l}\text { Major } \\
\text { finding on } \\
\text { admission }\end{array}$ & $\begin{array}{c}\text { Shock } \\
\text { presentation }\end{array}$ & Bleeding & $\begin{array}{c}\text { Surgical } \\
\text { approach }\end{array}$ & Injuries & $\begin{array}{c}\text { Surgical } \\
\text { procedure }\end{array}$ & $\begin{array}{c}\text { Cause } \\
\text { of } \\
\text { death }\end{array}$ \\
\hline \multirow[t]{2}{*}{ Ivatury [4] } & 1 & 15 & Male & Stabbing & Left & $\begin{array}{l}\text { Hypovolemic } \\
\text { shock }\end{array}$ & ED & Internal & Laparotomy & IA & na & Shock \\
\hline & 2 & 26 & Male & Stabbing & Left & Wound & Ward & Internal & Laparotomy & $\mid A$ & Repair & Shock $†$ \\
\hline \multirow[t]{2}{*}{ Gilroy [15] } & 3 & 45 & Male & Shooting & Left & $\begin{array}{l}\text { Hypovolemic } \\
\text { shock }\end{array}$ & ED & External & Laparotomy & $\begin{array}{l}\text { GA, } \\
\text { bowels, } \\
\text { bladder }\end{array}$ & $\begin{array}{l}\text { Ligation, } \\
\text { repair }\end{array}$ & Shock \\
\hline & 4 & 36 & Male & Stabbing & Left & $\begin{array}{c}\text { False } \\
\text { aneurysm }\end{array}$ & Theatre & External & *Laparotomy & SGA & Ligation & Sepsis \\
\hline Mercer [3] & 5 & 17 & Male & Shooting & Upper & $\begin{array}{l}\text { Hypovolemic } \\
\text { shock }\end{array}$ & ED & $\begin{array}{l}\text { External } \\
\& \\
\text { internal }\end{array}$ & Laparotomy & EIV & Repair & Shock \\
\hline \multirow[t]{3}{*}{ Ferraro [16] } & 6 & na & na & Shooting & na & $\begin{array}{l}\text { Hypovolemic } \\
\text { shock }\end{array}$ & ED & na & Laparotomy & $\begin{array}{l}\text { Pelvic } \\
\text { veins }\end{array}$ & $\begin{array}{c}\text { Pelvic } \\
\text { packing }\end{array}$ & Shock \\
\hline & 7 & na & na & Shooting & na & na & na & na & na & na & na & na \\
\hline & 8 & na & na & Shooting & na & na & na & na & na & na & na & na \\
\hline $\begin{array}{l}\text { DiGiacomo } \\
{[2]}\end{array}$ & 9 & na & na & Shooting & na & $\begin{array}{l}\text { Hypovolemic } \\
\text { shock }\end{array}$ & ED & Internal & Laparotomy & $\begin{array}{l}\text { CIA, CIV } \\
\text { Sigmoid } \\
\text { colon }\end{array}$ & na & Shock \\
\hline \multirow[t]{3}{*}{ Ceyran [19] } & 10 & na & Male & Stabbing & Left & $\begin{array}{l}\text { Hypovolemic } \\
\text { shock }\end{array}$ & ED & Internal & No surgery & IA & No & Shock \\
\hline & 11 & na & Male & Stabbing & Right & $\begin{array}{l}\text { Hypovolemic } \\
\text { shock }\end{array}$ & $\mathrm{ED}$ & External & Gluteal & SGA & No & Shockt \\
\hline & 12 & na & Male & Stabbing & Right & $\begin{array}{l}\text { Hypovolemic } \\
\text { shock }\end{array}$ & ED & External & Gluteal & SGA & No & Shockt \\
\hline \multirow{2}{*}{$\begin{array}{l}\text { Lesperance } \\
\text { [10] }\end{array}$} & $13-16$ & na & na & Shooting & na & na & na & na & na & na & na & na \\
\hline & $17-19$ & na & na & Blast & na & na & na & na & na & na & na & na \\
\hline
\end{tabular}

IA - iliac artery, GA - gluteal artery, SGA - superior gluteal artery, EIV - external iliac vein, IIA - internal iliac artery, CIA - common iliac artery, CIV - common iliac vein, ${ }^{*}$ Embolization was performed before laparotomy, $\dagger$ intraoperative deaths 
Table 3 The impact of gender, injury mechanism, injury severity, and intervention on survival of patients with penetrating trauma to the buttock $(n=240)$

\begin{tabular}{lllc}
\hline Factor & Groups & Alive/Death & P* \\
\hline Gender & male vs female & $228 / 9$ vs 12/0 & 0.4917 \\
Injury mechanism & stabbing vs shooting & $64 / 5$ vs 176/4 & 0.1281 \\
Hypovolemic shock & present vs not present & $17 / 8$ vs 224/1 & $<0.0001$ \\
Visceral/vascular injury & present vs not present & $61 / 9$ vs 179/0 & $<0.0001$ \\
Intervention extent & major vs minor/no surgery & $89 / 9$ vs 151/0 & 0.0006 \\
\hline
\end{tabular}

* Chi ${ }^{2}$-test with Yates' correction

drawing scale of damaged anatomical structures. Summing up data on large bowel and major junctional vessel injury demonstrated that prevalence of injury to large bowel was $11.2 \%(n=69)$; it was $2.9 \%$ for iliac artery or vein injury $(\mathrm{n}=18)$, and $1.3 \%(\mathrm{n}=8)$ for femoral artery or vein injury. 10 major vessels injured due to penetrating buttock trauma were not named. Gluteal arteries were damaged in 37 patients $(6.0 \%)$.

\section{Pattern of major injuries related to stabbing}

$99(63 \%)$ major injuries were identified in the subset of 158 patients with stab wounds (Figure 2). The prevalence of major vessel, visceral, sciatic nerve, and ligament/joint injury was $34.8 \%(\mathrm{n}=55), 24.1 \%(\mathrm{n}=$ $38), 2.5 \%(n=4)$, and $1.3 \%(n=2)$, respectively. Rectum, superior gluteal artery, and iliac artery were the most frequently damaged major structures accounting for $19.0 \%, 17.7 \%$, and $7.0 \%$. In total, there were 32 injuries to gluteal arteries (20.3\%), 13 injuries to iliac artery or vein $(8.2 \%)$, and 6 injuries to femoral artery or vein (3.8\%).

\section{Pattern of major injuries related to shot wounds}

225 major injuries were identified in the subset of 457 patients with gunshot injury (Figure 3). There were 166 visceral injuries (36.3\%), 27 injuries to the bony pelvis

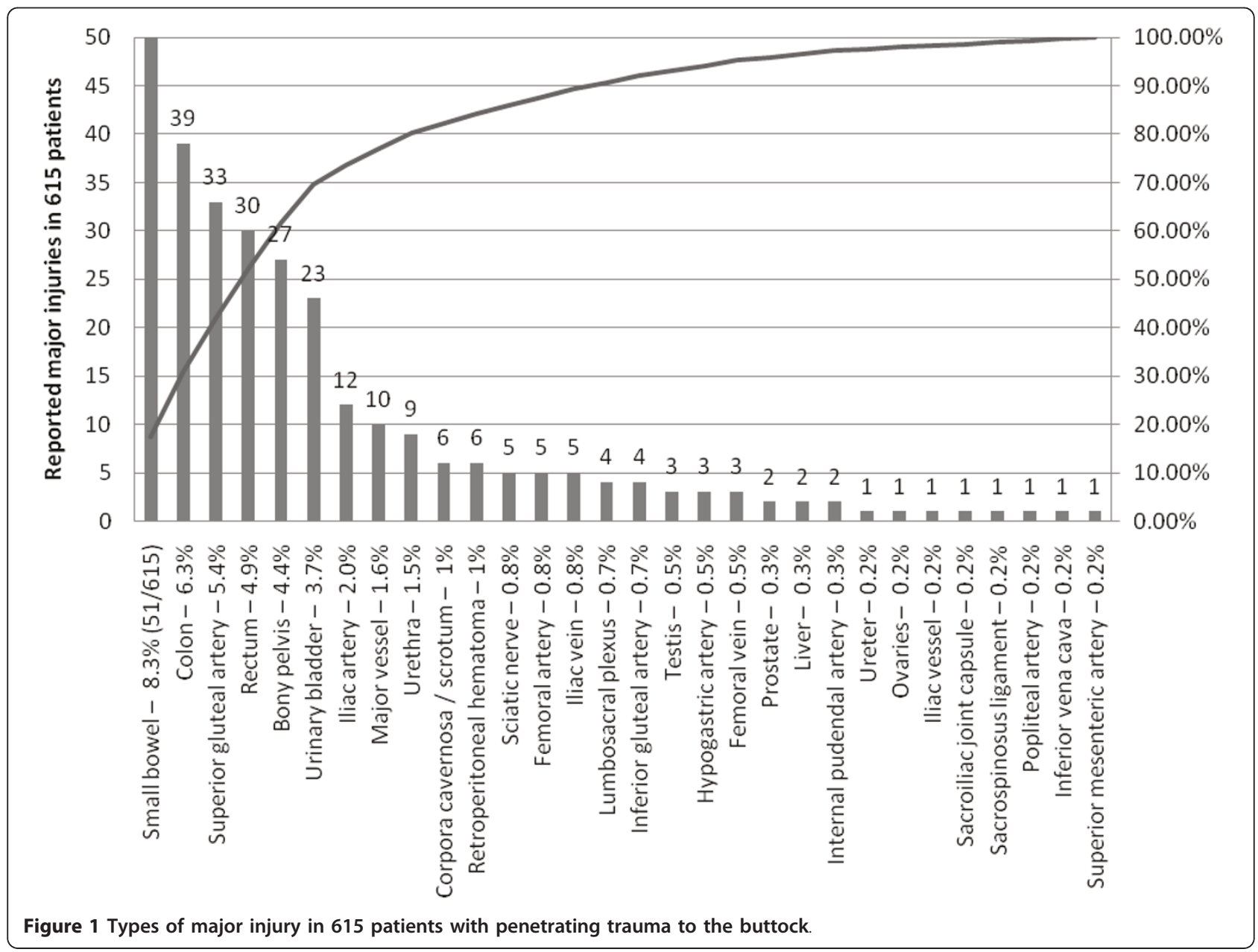




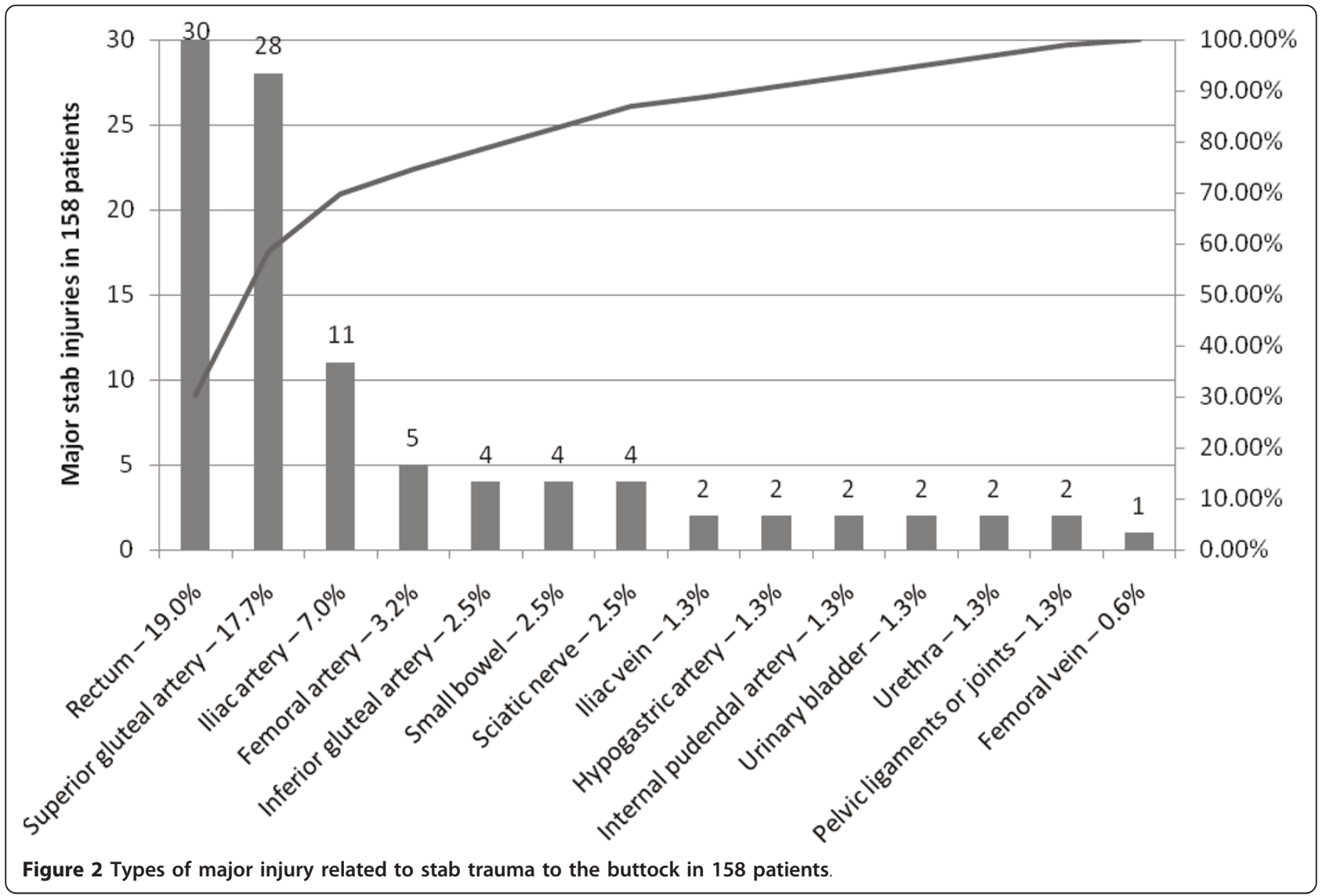

(5.9\%), 26 injuries to major vessel (5.7\%), 6 cases of retroperitoneal hematoma (1.3\%), and 5 neurologic injuries (1.1\%). The spectrum of major injuries associated with gunshot trauma to the buttock comprised 21 different types of injury. Injury of small bowel, colon, rectum, bony pelvis, and bladder were most frequent with $10.3 \%$, $8.5 \%, 8.1 \%, 5.9 \%$, and $4.6 \%$, respectively. When colon and rectal injuries were collated, the prevalence of large bowel injury increased to $16.6 \%(n=76)$.

The pattern of major injury relating to injury mechanism Table 4 demonstrates a higher frequency for all visceral and skeletal pelvic injuries in the patients with shot wounds. Injuries to the organs located more distally from the wound site (colon, small bowel, and bladder) were far more frequently damaged in patients with shot wounds to the buttock. Rectum and major vessels of the region (iliac vessels, femoral vessels, and gluteal arteries) were damaged more frequently in patients with stab wounds to the buttock.

\section{Penetrating injuries to the upper vs lower zone of the buttock}

A subset including 97 cases from two retrospective studies [3,17] and six case reports [21,22,25,27,29] provided data to assigns the main wound site to the upper or lower buttock region. Statistical results regarding penetrating injuries above and below the intertrochanteric line are shown in Table 5 . There were 64 wounds to the upper zone (66.0\%): 26 of them were related to stabbing and 38 to shooting. The lower zone of the buttock was targeted 33 times (34.0\%): 15 subjects had stab wounds and 18 subjects had shot wounds. A prevalence of major injuries, either visceral/vascular, bony pelvis or sciatic nerve, was higher in patients with the entrance wound position above the intertrochanteric line. Visceral/vascular injuries were more frequent in patients with penetrating wounds in the upper zone of the buttock (25/64, 39.1\% vs 6/33, 18.2\%; OR, 2.88; CI, 1.04-7.98; $P<0.05)$. The sensitivity of this test was 0.81 , the positive predictive value was 0.39 . Injury of soft tissue alone was more frequent in patients with penetrating injury to the lower zone of the buttock $(32 / 64,50.0 \%$ vs $26 / 33,78.8 \%$; $P<$ $0.05)$. The sensitivity of this test was 0.55 , positive predictive value was 0.5 .

\section{Discussion}

It may be helpful to remind ourselves of the former surgical perspective on buttock trauma. Feigenberg (1992) reviewed four papers on stab wounds to the buttock 


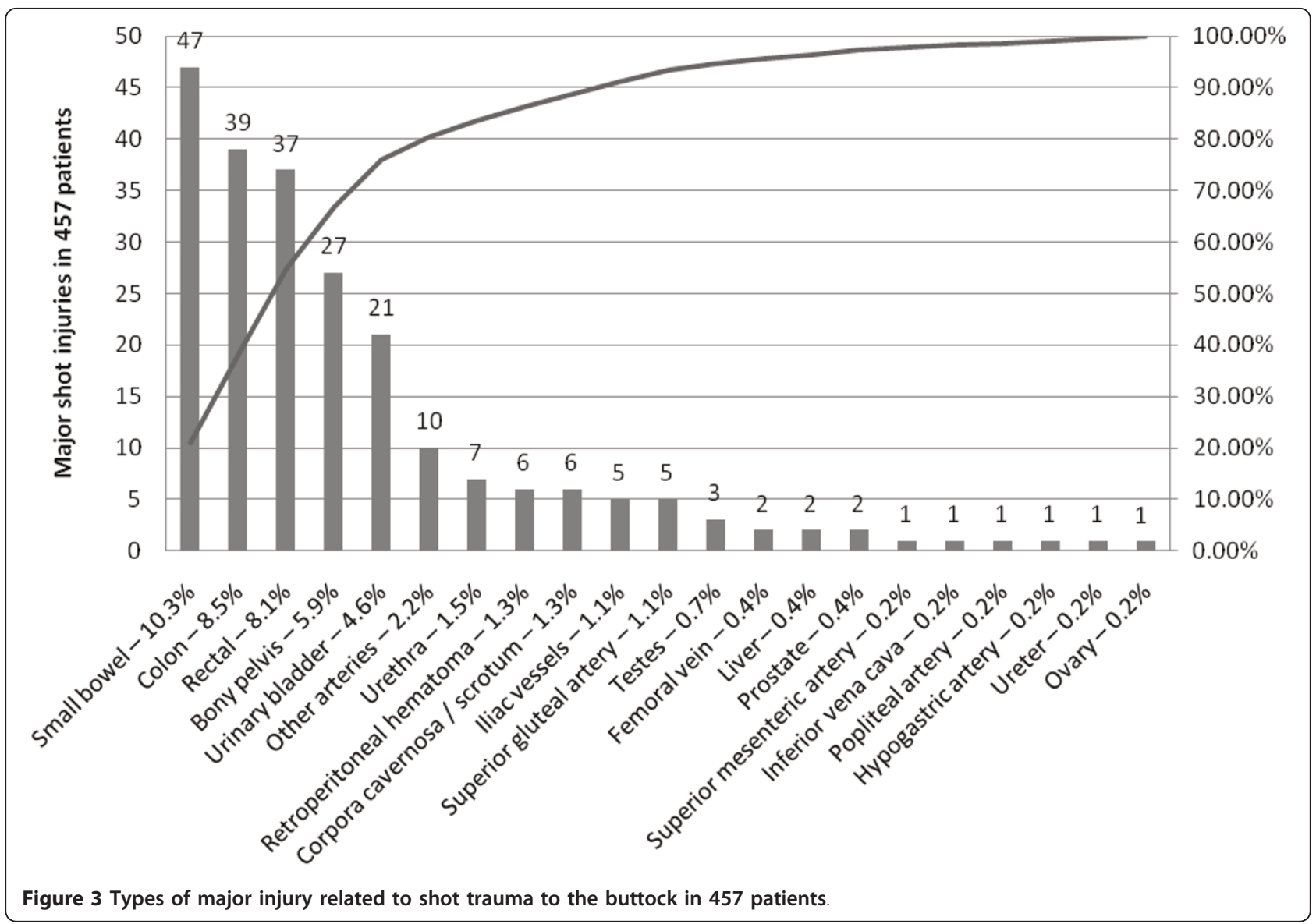

and concluded that any stab wound to this body region should be regarded as potentially dangerous and every effort should be made to locate possible injuries [6]. Salim and Velmahos' review (2002) on abdominal gunshot wounds contains only one chapter regarding injury to the buttocks [7] and refers to one reference [11] pointing out that haemodynamically stable patients should be triaged (operation $v s$ adjunct investigations) according to findings of physical examination. Aydin (2007) highlighted the importance of placing an acute

Table 4 Stabbing vs shooting related major injuries of the buttock

\begin{tabular}{|c|c|c|c|c|c|}
\hline Injuries & Stab wound $n=158$ & Shot wound $n=457$ & Odds Ratio & 95\% Confidence Internal & $\mathrm{P}^{*}$ \\
\hline Visceral: & $38(24 \%)$ & $166(36 \%)$ & 0.56 & $0.37-0.84$ & 0.006 \\
\hline Colon & 0 & $39(9 \%)$ & 0.24 & $0.11-0.50$ & 0.0003 \\
\hline Small bowel & $4(3 \%)$ & $47(10 \%)$ & 0.23 & $0.08-0.64$ & 0.004 \\
\hline Rectal & $30(19 \%)$ & $37(8 \%)$ & 2.66 & $1.58-4.48$ & 0.0003 \\
\hline Bladder & $2(1 \%)$ & $21(5 \%)$ & 0.33 & $0.08-1.42$ & 0.0097 \\
\hline Major vessel: & $55(35 \%)$ & $26(6 \%)$ & 8.85 & $5.30-14.80$ & 0.0001 \\
\hline Gluteal arteries: & $32(20 \%)$ & $5(1 \%)$ & 22.96 & $8.76-60.14$ & 0.0001 \\
\hline Superior gluteal artery & $28(18 \%)$ & $5(1 \%)$ & 19.47 & $7.37-51.43$ & 0.0001 \\
\hline Inferior gluteal artery & $4(3 \%)$ & 0 & 49.97 & $5.28-473.4$ & 0.005 \\
\hline Iliac vessels: & $13(8 \%)$ & $5(1 \%)$ & 8.10 & $2.84-23.12$ & 0.0001 \\
\hline Iliac artery & $7(4 \%)$ & $1(0.2 \%)$ & 8.10 & $2.84-23.12$ & 0.0003 \\
\hline Internal iliac artery & $4(3 \%)$ & 0 & 49.97 & $5.28-473.4$ & 0.0046 \\
\hline Femoral vessels: & $6(4 \%)$ & $2(0.4 \%)$ & 8.98 & $1.79-44.96$ & 0.005 \\
\hline Femoral artery & $5(3 \%)$ & 0 & 50.30 & $6.72-376.39$ & 0.001 \\
\hline Sciatic nerve & $4(3 \%)$ & $1(0.2 \%)$ & 11.84 & $1.31-106.78$ & 0.023 \\
\hline Bony pelvis & 0 & $27(6 \%)$ & 0.25 & $0.10-0.59$ & 0.004 \\
\hline
\end{tabular}

Values in parenthesis are percentages. ${ }^{*} \mathrm{Z}$ test. 
Table 5 Penetrating injuries to the upper zone vs lower zone of the buttock

\begin{tabular}{|c|c|c|c|c|c|}
\hline Injuries & Upper zone* $n=64$ & Lower zonet $\mathrm{n}=33$ & Odds Ratio & 95\% Confidence Internal & $\mathrm{P} \neq$ \\
\hline Buttock soft tissue & $32(50 \%)$ & $26(79 \%)$ & 0.27 & $0.10-0.71$ & 0.012 \\
\hline SW & $13(50 \%)$ & $10(67 \%)$ & 0.5 & $0.13-1.87$ & 0.478 \\
\hline GSW & $19(50 \%)$ & $16(89 \%)$ & 0.13 & $0.03-0.62$ & 0.012 \\
\hline Visceral/Vascular/Bony & $29(45 \%)$ & $6(18 \%)$ & 3.73 & $1.35-10.26$ & 0.016 \\
\hline SW & $11(42 \%)$ & $4(27 \%)$ & 2.02 & $5.51-8.05$ & 0.506 \\
\hline GSW & $18(47 \%)$ & $2(11 \%)$ & 7.2 & $1.45-35.73$ & 0.019 \\
\hline Visceral/Vascular & $25(39 \%)$ & $6(18 \%)$ & 2.88 & $1.04-7.98$ & 0.063 \\
\hline SW & $11(42 \%)$ & $4(27 \%)$ & 2.02 & $5.51-8.05$ & 0.506 \\
\hline GSW & $14(37 \%)$ & $2(11 \%)$ & 4.67 & $0.93-23.37$ & 0.094 \\
\hline Bony pelvis & $4(6 \%)$ & 0 & 4.78 & $0.58-39.10$ & 0.353 \\
\hline SW & 0 & 0 & - & - & - \\
\hline GSW & $4(11 \%)$ & 0 & 4.90 & $0.58-41.69$ & 0.383 \\
\hline Sciatic nerve & $3(5 \%)$ & $1(3 \%)$ & 1.57 & $0.16-15.75$ & 0.882 \\
\hline SW & $2(8 \%)$ & $1(7 \%)$ & 1.17 & $0.10-14.06$ & 0.616 \\
\hline GSW & $1(3 \%)$ & 0 & 4.37 & $0.07-290.2$ & 0.700 \\
\hline
\end{tabular}

* 26 stab wounds, and 38 gunshot wounds, † 15 stab and 18 gunshot wounds. Values in parenthesis are percentages. $¥ Z$ test . SW - stab wound, GSW - gunshot wound

false aneurysm in the differential diagnosis of an indurate, fluctuant, warm, erythematous posttraumatic gluteal mass [8]. The key statements of the review provided by Butt (2009) [9] are based on the summary of three papers $[11,12,37]$ on gunshot wounds to the buttocks, back, and pelvis: firstly, the management of gunshot wounds of the buttocks should follow the same principles with anterior abdomen gunshot wounds; secondly, clinical examination is a reliable predictor for the need of an operation; thirdly, a rigid sigmoidoscopy is introduced per routine for all patients.

Case reports on penetrating buttock injury [6,8,19-33] highlight the importance of a thorough and aggressive evaluation of the patient [6], observation [23,27], prompt differential diagnosis $[8,21,30,31]$, immediate assessment of the lower urinary tract $[21,22]$, and lately the value of dynamic 2D and 3D CT-scanning and angiography [28]. They also highlight rare complications following highvelocity or low-velocity gunshot injury to the buttock where the bullet or pellet migrates to major veins such as inferior cava vein and hepatic veins [29] or if it reaches the right ventricle of the heart [23], needing a broad range of approaches ranging from open surgery to angioembolization $[6,21,22]$, transjugular extraction of bullet from middle hepatic vein [29], image navigation surgery [33], gluteal surgery [28,32], laparoscopy [24], and laparotomy $[6,20,21,25]$.

Our analytical review demonstrates that penetrating trauma to the buttock is a serious diagnostic and clinical concern with a mortality rate of $2.9 \%$. Mortality of penetrating stab injuries to the buttock is comparable to that of extra-buttock regions of the body, such as penetrating injury to the posterior abdomen is $0-2 \%$ [37-39], the anterior abdomen $0-4.4 \%$ [40-43], the thoracoabdominal area $2.1 \%$ [44], and the chest $2.5-5.6 \%$ [44-46]. Mortality may be less in cohorts with isolated stab injury to the chest (1.46\%) [45], or after exclusion of cardiac injuries $(0.8 \%)$ [44]. Regarding pelvic or transpelvic gunshot trauma, mortality rates vary from $0-12.2 \%[11,47,48]$. Cohorts with gunshot wounds to the limbs may show no mortality $[49,50]$. We conclude that penetrating injuries to the buttock poses a similar threat to the patient as penetrating trauma of any other body region.

Despite the fact that stab wound primarily cause locoregional damage, whilst gunshot trauma is associated with frequent extraterritorial injury, stab wounds $(3.8 \%$ mortality rate) are even more dangerous than missile wounds per se or gunshot wounds specifically $(2.6 \%$ and $2.2 \%$ mortality rate, respectively). Injury of buttock due to impalement remains uncommon [26,51]. It is therefore recommended to classify impalement related injuries as a separate category of penetrating injuries [52].

Analysis of the associated major injuries due to penetrating trauma to the buttock reveals several unexpected particularities. The most commonly damaged particular organs and vessels were, in descending order, small bowel, colon, superior gluteal artery, and rectum. Injury of iliac artery and/or vein was a rare, but relevant finding with $2.9 \%$. This counterintuitive finding is better understood on analysis of subgroups created according to injury mechanism.

As expected, stabbings were most frequently associated with injuries to gluteal arteries (20.3\%), rectum (19.0\%), and iliac vessels (8.2\%). The prevalence of injuries to femoral artery or vein was 3.8\%. Gunshot injuries frequently result in wider organ damage involving small 
bowel (10.3\%), colon (8.5\%), rectum (8.1\%), bony pelvis (5.9\%), and bladder injuries (4.6\%). Table 4 provides ample evidence that gunshot and stab trauma of the buttock are actually two separate clinical entities. They require different diagnostic and surgical approaches which are summarised in Figure 4. In our view, such an approach based on empiric evidence might usefully supersede former algorithms by trying to address particular aspects of buttock trauma $[2,5,14,17]$.

This review confirms the conclusion of two other authors $[3,17]$ suggesting that injuries of upper zone of the buttock are associated with higher probability of viscus or major vessel injury comparing with injuries to the lower zone of the buttock. Table 5 reveals significant differentiation of injury patterns according to zone of primary injury site. However, the low positive predictive value does not recommend to rely on this criterion, for management strategies based on division of the buttock. On any account, the frequency of extraregional injury should prompt an aggressive and speedy computed tomography imaging approach to the entire abdomen and pelvis, complemented by a chest $\mathrm{x}$-ray in all gunshot wounds to the buttock.
The current review contains a significant amount of historical data, bringing the use of endovascular approaches to only $1.8 \%$ in the current cohort. The advent of interventional radiological techniques should enable embolisation of pelvic vessels beside the level of the common or external iliac vessels [36,53].

Selective non-operative management of penetrating trauma to the buttock in stable patients without evidence of major organ injury is a successful approach [11]. Serial clinical examination should include per rectal examination, rigid sigmoidoscopy, and urinanalysis because of quite high probability of colorectal $(11.2 \%)$ as well as bladder, urethra, and ureter injury (5.4\%).

A classification of CT findings into three main groups of subset in relation to stable patients (abdominal/pelvis injury, gluteal vessel injury, and femoral vessel injury) is another feature of the algorithm (Figure 4). The rationale of this is the following: the buttocks should be regarded as a distinct anatomical/junctional zone in trauma surgery because patterns of penetrating injury and clinical characteristics as well as implications of buttock trauma disclosed in this paper correspond with general hallmarks of junctional trauma [54].

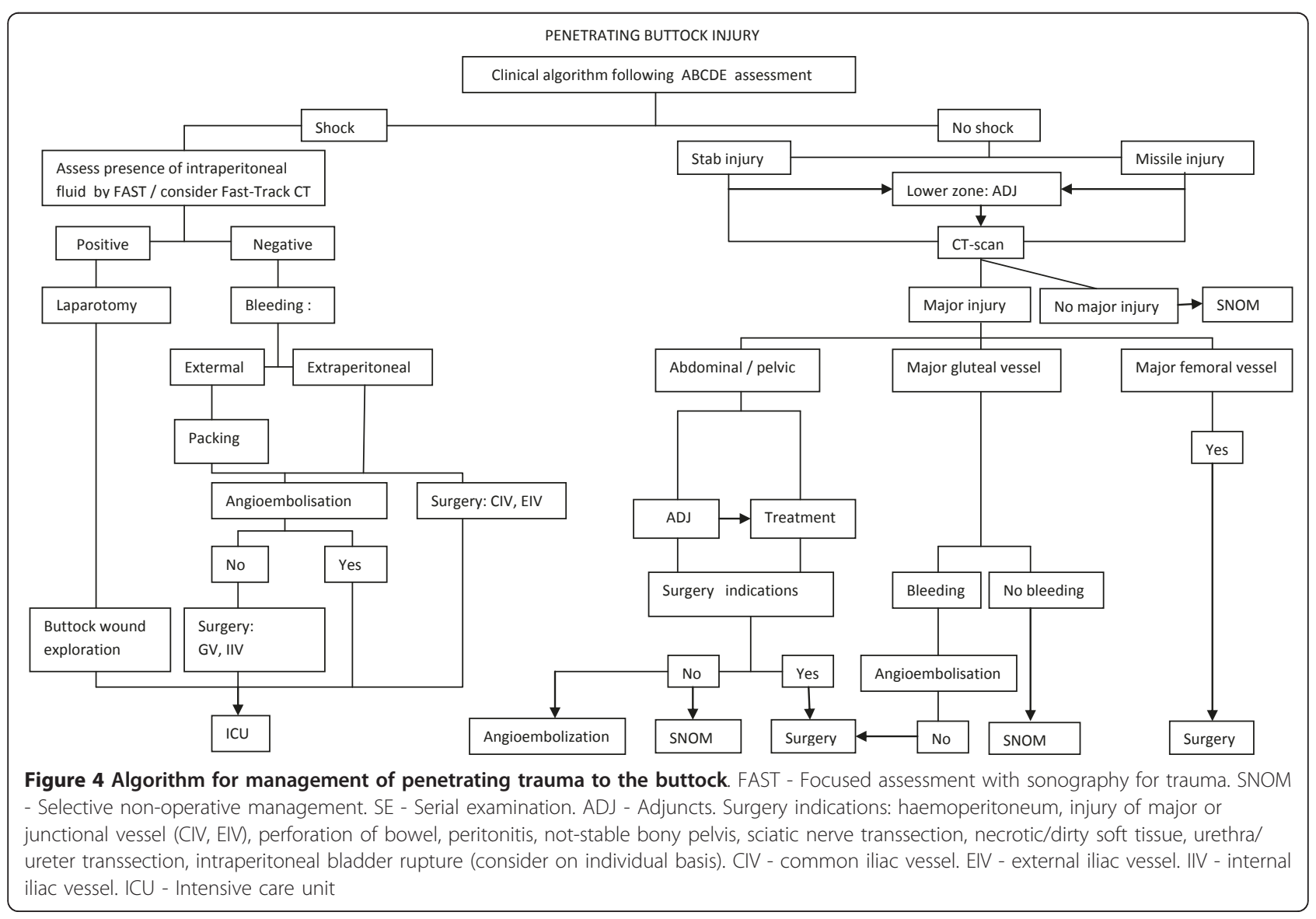


In terms of injury severity score, only Ferraro [16] and Lesperance [10] used the ISS scale. It is important to emphasise coding technique for penetrating buttock injury according to newest AIS $2005^{\circ}$ Update 2008 [55]. It indicates that superficial (minor) penetrating injury to the buttock should be regarded as grade 1 (code 816011.1). When there is tissue loss $>25 \mathrm{~cm}^{2}$, it should be regarded as grade 2 injury (code 816012.2 ), and when it is associated with blood loss $>20 \%$ by volume, it has to be regarded as grade 3 injury (816013.3). Such injuries should be assigned to the external body region when calculating the ISS. However, if underlying anatomical structures are involved, documented diagnoses should be coded only, and they should be assigned to either the lower extremity body region or abdomen. Penetrating injuries involving a bone is coded as open fracture to the specific bone.

There are several limitations of this review. Publication bias, retrospective approach, clustered data, complexity of some injuries, and constrained nature of this study are the factors which undoubtedly cause our bias views. Prospective networked studies would be a better approach to the problem. The current review may help to design such studies.

In conclusion, penetrating buttock trauma should be regarded as a life-threatening injury with impact beyond the pelvis until proven otherwise.

\section{Authors' contributions}

RL and KMS equally participated in the design of the study and interpretation of data. RL performed the literature review, statistical analysis of data, and drafting. KMS carried out the critical revision of the manuscript. Both authors read and approved the final manuscript.

\section{Competing interests}

The authors declare that they have no competing interests.

Received: 14 August 2011 Accepted: 13 October 2011

Published: 13 October 2011

\section{References}

1. Trunkey D: Torso trauma. Curr Probl Surg 1987, 24:4.

2. DiGiacomo JC, Schwab CW, Rotondo MF, Angood PA, McGonigal MD, Kauder DR, Phillips GR: Gluteal gunshot wounds: who warrants exploration? J Trauma 1994, 37:622-628

3. Mercer DW, Buckman RF Jr, Sood R, Kerr TM, Gelman J: Anatomic considerations in penetrating gluteal wounds. Arch Surg 1992 127:407-410

4. Ivatury RR, Rao PM, Nallathambi M, Gaudino J, Stahl WM: Penetrating gluteal injuries. J Trauma 1982, 22:706-709.

5. Vo NM, Russell JC, Becker DR: Gunshot wounds to the buttocks. Am Surg 1983, 49:579-581.

6. Feigenberg Z, Ben-Baruch D, Barak R, Zer M: Penetrating stab wound of the gluteus-a potentially life-threatening injury: case reports. $J$ Trauma 1992, 33:776-778.

7. Salim A, Velmahos GC: When to operate on abdominal gunshot wounds. Scand J Surg 2002, 91:62-66.

8. Aydin A, Lee CC, Schultz E, Ackerman J: Traumatic inferior gluteal artery pseudoaneurysm: case report and review of literature. Am J Emerg Med 2007, 25:488.e1-3.
9. Butt MU, Zacharias N, Velmahos GC: Penetrating abdominal injuries: management controversies. Scand J Trauma Resusc Emerg Med 2009, 17:19.

10. Lesperance K, Martin MJ, Beekley AC, Steele SR: The significance of penetrating gluteal injuries: an analysis of the Operation Iraqi Freedom experience. J Surg Educ 2008, 65:61-66.

11. Velmahos GC, Demetriades D, Cornwell EE, Asensio J, Belzberg H, Berne TV: Gunshot wounds to the buttocks: predicting the need for operation. Dis Colon Rectum 1997, 40:307-311.

12. Velmahos GC, Demetriades D, Cornwell EE III: Transpelvic gunshot wounds: routine laparotomy or selective management? World J Surg 1998, 22:1034-1038.

13. Maull Kl, Snoddy JW, Haynes BW Jr: Penetrating wounds of the buttock. Surg Gynecol Obstet 1979, 149:855-857.

14. Fallon WF Jr, Reyna TM, Brunner RG, Crooms C, Alexander RH: Penetrating trauma to the buttock. South Med J 1988, 81:1236-1238.

15. Gilroy D, Saadia R, Hide G, Demetriades D: Penetrating injury to the gluteal region. J Trauma 1992, 32:294-297.

16. Ferraro FJ, Livingston DH, Odom J, Swan KG, McCormack M, Rush BF Jr: The role of sigmoidoscopy in the management of gunshot wounds to the buttocks. Am Surg 1993, 59:350-352.

17. Makrin V, Sorene ED, Soffer D, Weinbroum A, Oron D, Kluger Y: Stab wounds to the gluteal region: a management strategy. J Trauma 2001, 50:707-710.

18. Susmallian S, Ezri T, Elis M, Dayan K, Charuzi I, Muggia-Sullam M: Gluteal stab wound is a frequent and potentially dangerous injury. Injury 2005, 36:148-150.

19. Ceyran H, Akçali Y, Özcan N, Tasdemir K: Isolated penetrating gluteal injuries. Perspect Vasc Surg Endovasc Ther 2009, 21:253-256.

20. Knight RJ: Resuscitation of battle casualties in South Vietnam: experiences at the First Australian Field Hospital. Resuscitation 1973, 2:17-31.

21. Mamode $\mathrm{N}$, Reid AW: Haemorrhage following penetrating gluteal trauma. Br J Surg 1994, 81:203-204.

22. Rub R, Madeb R, Kluger $Y$, Chen T, Avidor $Y$ : Posterior urethral disruption secondary to a penetrating gluteal injury. Urology 2000, 56:509.

23. Obermeyer RJ, Fecher A, Erzurum VZ, DeVito PM: Embolization of bullet to the right ventricle. Am J Surg 2000, 179:189.

24. Kalimi R, Angus LD, Gerold T, DiGiacomo JC, Weltman D: Bullet embolization from the left internal iliac vein to the right ventricle. J Trauma 2002, 52:772-774.

25. Carrick MM, Morel AN, Pham HQ: Shotgun wounds to the buttocks, sacrum, and rectum. J Trauma 2007, 62:552.

26. Napier F, Fountain-Polley S, Kallapa C: Images in paediatrics: Ironing board impalement. Arch Dis Child 2007, 92:758.

27. van Oldenrijk J, Unlü C, van Wagensveld BA: Perforation of the ileum after a stab wound of the gluteal region: a case report. Emerg Med J 2007, 24:737-738.

28. Ramasamy A, Hinsley DE, Brooks AJ: The use of improvised bullet markers with 3D CT reconstruction in the evaluation of penetrating trauma. $J R$ Army Med Corps 2008, 154:239-241.

29. Raikar SS, Jureidini SB, Balfour IC, Tinker K: The fantastic journey of a bullet: out with a snare. Pediatr Cardiol 2010, 31:108-110.

30. Demetriades D, Rabinowitz B, Sofianos C: Gluteal artery aneurysms. Br J Surg 1988, 75:494.

31. Holland AJ, Ibach EG: False aneurysm of the inferior gluteal artery following penetrating buttock trauma: case report and review of the literature. Cardiovasc Surg 1996, 4:841-843.

32. Culliford AT, Cukingham RA, Worth MH Jr: Aneurysms of the gluteal vessels: their etiology and management. J Trauma 1974, 14:77- 81

33. Chappell ET, Pare L, Salepour M: Fluoroscopic image guidance for minimally invasive extraction of a bullet from the gluteus maximus. $J$ Trauma 2006, 60:664-667.

34. Scalea TM: Invited commentary on Velmahos, G.C., et al: Transpelvic gunshot wounds: routine laparotomy or selective management? World J Surg 1998, 22:1038.

35. DiGiacomo JC, Schwab CW, Kauder DR, Rotondo MF: Re: Velmahos, G.C., et al: Transpelvic gunshot wounds: routine laparotomy or selective management? World J Surg 1999, 23:619-620. 
36. Rasmussen TE: Commentary on "Isolated penetrating gluteal injuries: a potentially life-threatening trauma". Perspect Vasc Surg Endovasc Ther 2009, 21:257-258, discussion 258 .

37. Velmahos GC, Demetriades D, Foianini E, Tatevossian R, Cornwell EE, Asensio J, Belzberg H, Berne TV: A selective approach to the management of gunshot wounds to the back. Am J Surg 1997, 174:342-346.

38. Peck JJ, Berne TV: Posterior abdominal stab wounds. J Trauma 1981, 21:298-306.

39. Demetriades D, Rabinowitz B, Sofianos C, Charalambides D, Melisas J, Hatzitheofilou C, Da Silva J: The management of penetrating injuries of the back. A prospective study of 230 patients. Ann Surg 1988, 207:72-74

40. Shaftan GW: Indications for operation in abdominal trauma. Am J Surg 1960, 99:657-664.

41. Goins WA, Anderson BB: Abdominal trauma revisited. J Nati Med Assoc 1991, 83:883-888.

42. Leppäniemi A, Haapiainen R: Diagnostic laparoscopy in abdominal stab wounds: a prospective, randomized study. J Trauma 2003, 55:636-645.

43. Ohene-Yeboah M, Dakubo JCB, Boakye F, Naeeder SB: Penetrating abdominal injuries in adults seen at two teaching hospitals in Ghana. Ghana Med J 2010, 44:103-108.

44. Mandal AK, Oparah SS: Unusually low mortality of penetrating wounds of the chest. Twelve years' experience. J Thorac Cardiovasc 1989, 97:119-125.

45. Inci I, Ozçelik C, Taçyildiz I, Nizam O, Eren N, Ozgen G: Penetrating chest injuries: unusually high incidence of high-velocity gunshot wounds in civilian practice. World J Surg 1998, 22:438-442.

46. Fullum TM, Siram SM, Righini M: Stab wounds to the chest: a retrospective review of 100 consecutive cases. J Nat Med Assoc 1999, 82:109-112.

47. Duncan AO, Philips TF, Scalea TM, Maltz SB, Atweh NA, Sclafani SJ: Management of transpelvic gunshot wounds. J Trauma 1989, 29:1335-1340.

48. Navsaria PH, Edu S, Nicol AJ: Nonoperative management of pelvic gunshot wounds. Am J Surg 2011, 201:784-788, Epub 2010 Sep 29.

49. Stewart MP, Kinninmonth A: Shotgun wounds of the limbs. Injury 1993, 24:667-670.

50. Burg A, Nachum G, Salai M, Haviv B, Heller S, Velkes S, Dudkiewicz l: Treating civilian gunshot wounds to the extremities in a level 1 trauma center: our experience and recommendations. IMAJ 2009, 11:546-551.

51. O'Leary ST, Waterworth P, Fountain SW: Multiple impalement injury-a remarkable survival. Injury 1996, 27:589-590.

52. Eachempati SR, Barie PS, Reed RL: Survival after transabdominal impalement from a construction injury: a review of the management of impalement injuries. J Trauma 1999, 47:864-866.

53. Guven K, Rozanes I, Ucara A, Poyanli A, Yanarb H, Acunas B: Pushable springcoil embolization of pseudoaneurysms caused by gluteal stab injuries. Eur J Radiol 2010, 73:391-395.

54. Tai NRM, Dickson EJ: Military junctional trauma. JR Army Med Corps 2009, 155:285-292.

55. Association for the Advancement of Automotive Medicine:Edited by: Gennarelli TA, Wodzin E. Barrington, IL, USA; 2008:, Abbreviated Injury Scale O2005. Update 2008..

doi:10.1186/1749-7922-6-33

Cite this article as: Lunevicius and Schulte: Analytical review of 664 cases of penetrating buttock trauma. World Journal of Emergency Surgery 2011 6:33.

\section{Submit your next manuscript to BioMed Central and take full advantage of:}

- Convenient online submission

- Thorough peer review

- No space constraints or color figure charges

- Immediate publication on acceptance

- Inclusion in PubMed, CAS, Scopus and Google Scholar

- Research which is freely available for redistribution

Submit your manuscript at www.biomedcentral.com/submit 